\title{
Effect of activation temperature on surface basicity of natural aluminosilicates
}

\author{
(C) 2021 Novikova L.A. ${ }^{1}$, Khodosova N.A. ${ }^{1}$, Belchinskaya L.I. ${ }^{1}$, Roessner F. ${ }^{2}$ \\ ${ }^{I}$ Voronezh State University of Forestry and Technologies named after G.F. Morozov, \\ Voronezh, Russian Federation \\ ${ }^{2}$ Carl von Ossietzky University of Oldenburg, Oldenburg, Germany
}

Received 9.10.2020

DOI: $10.17308 /$ sorpchrom.2021.21/3198

Montmorillonite and nontronite are layered aluminosilicates of smectite group minerals widely demanded in many industries owing to their unique physical-chemical and other properties. By thermal activation of raw clays there are variations in their porosity, surface area and physical-chemical properties, including formation and redistribution of surface active site of acid-base or redox character. The aim of present studies included investigation of the effect of thermal activation on the character of distribution and a number of basic sites on the surface of natural layered aluminosilicates by means of the new method of inverse thermoprogrammed desorption of $\mathrm{CO}_{2}$.

Samples of natural aluminosilicates rich in montmorillonite (Montmorillonite $67 \%$, illite 5\%, quartz $5 \%$, feldspars $21 \%$ ) and nontronite (nontronite $70 \%$, illite $10 \%$, kaolinite $5 \%$, quartz $10 \%$, feldspars $8 \%$ ) were characterized by XRD, XRF, BET $\mathrm{N}_{2}$ adsorption techniques. To probe surface basicity and determine the number of basic sites a new iTPD- $\mathrm{CO}_{2}$ was used. Prior the iTPD- $\mathrm{CO}_{2}$ measurement $100 \mathrm{mg}$ of a sample was activated at $200,300,400^{\circ} \mathrm{C}$, then cooled down and loaded with $\mathrm{CO}_{2}\left(3 \mathrm{ml} / \mathrm{min}\right.$ flow rate of $\mathrm{CO}_{2}$ for $30 \mathrm{~min}$ ). Next, the reactor was flushed by $5 \mathrm{ml} / \mathrm{min} \mathrm{N}_{2}$-flow to desorb weakly sorbed $\mathrm{CO}_{2}$. The iTPD-CO profiles were recorded within $20-800^{\circ} \mathrm{C}$ at a $20^{\circ} \mathrm{C} / \mathrm{min}$ heating rate and treated using ChemStation software.

The experimental profiles of $\mathrm{CO}_{2}$ desorption for $\mathrm{Mt}$ and $\mathrm{Nt}$ samples observed two temperature regions. Low temperature peaks evolved around $80-90^{\circ} \mathrm{C}$ for $\mathrm{Mt}$ and between $110-127^{\circ} \mathrm{C}$ for $\mathrm{Nt}$ were most likely related to the weak basic sites, whereas high temperature peaks around 510 and $620^{\circ} \mathrm{C}$ for Mt and above $320^{\circ} \mathrm{C}$ for Nt testified to stronger ones. The reasoning of the obtained iTPD-profiles was done considering thermal behavior of layered aluminosilicates.

The total basicity of Nt and Mt samples was 359.2 and $209.9 \mu \mathrm{mol} / \mathrm{g}$ respectively. The 1.6 times higher basicity of $\mathrm{Nt}$ was, obviously, caused by its phase and chemical composition and developed surface area and porosity. At higher activation temperatures the number of weak basic sites related to hydroxyl groups of adsorbed water molecules gradually decreased, namely, by 21 times for Mt and by 2.8 times for Nt.

Dehydroxylation of structural $\mathrm{Al}-\mathrm{OH}, \mathrm{Fe}-\mathrm{OH}, \mathrm{Mg}-\mathrm{OH}$ above $200^{\circ} \mathrm{C}$, which becomes irreversible above $300^{\circ} \mathrm{C}$, provided formation of residual oxygen atoms and their contribution to population of stronger basic sites. In accordance with thermal behavior of dioctahedral smectites, is assumed that strong basic sites of Mt are trans- and cis-vacant $\mathrm{Al}-\mathrm{OH}$ groups dehydroxylating correspondingly at $\sim 550$ and $650^{\circ} \mathrm{C}$. Fe-rich sample of Nt rapidly lost hydroxyls at rather lower temperatures that resulted in more heterogeneous distribution of strong basic sites of varying strength. At higher activation temperatures the ratio of stronger sites number to weak sites increased from 23 to 200 for Mt, whereas for Nt this ratio varied between 54-67 times. In general, total basicity of $\mathrm{Mt}$ and $\mathrm{Nt}$ decreased by 2.2-2.3 times as a result of their dehydration and dehydroxylation by thermal activation. The normalized values of basicity per unit surface area $\left(\mathrm{B}_{\Sigma} / \mathrm{S}, \mu \mathrm{mol} / \mathrm{m}^{2}\right)$ were 1,5 times higher for Mt surface, testifying to higher occupancy and density of active sites for Mt than that of Nt.

Keywords: montmorillonite, nontronite, thermal activation, inverse $\mathrm{TPD}-\mathrm{CO}_{2}$, surface basicity. 


\section{Introduction}

Montmorillonite and nontronite are layered aluminosilicates belonging to smectite group minerals formed during weathering of igneous rocks in an alkaline media and constituting soil loams and sedimentary rocks [1-3]. The structure of monemotillonite and nontronite are represented by three-layer packages (T-O-T) of silicaoxygen tetrahedral and alumina-oxygen octahedra. Different extent of isomorphic substitutions of $\mathrm{Si}^{4+}$ for $\mathrm{Al}^{3+}$, and $\mathrm{Al}^{3+}$ for $\mathrm{Fe}^{2+}$, $\mathrm{Fe}^{3+}$ or $\mathrm{Mg}^{2+}$ in tetrahedral or octahedral sheets, respectively, leads to origin of 0.20.6 negative layer charge in smectites [1] The chemical composition of octahedral sheet is the major difference of montmorillonite from nontronite that is revealed in their general chemical formulas $[1,3]$ :

$$
\begin{aligned}
& \text { Montmorillonite }
\end{aligned}
$$

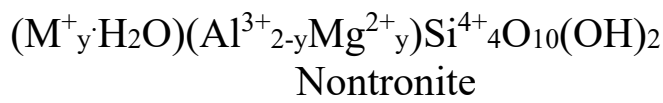

$$
\begin{aligned}
& \left(\mathrm{M}_{\mathrm{y}}^{+} \mathrm{H}_{2} \mathrm{O}\right) \mathrm{Fe}^{3+} 2\left(\mathrm{Si}^{4+}{ }_{4-\mathrm{x}} \mathrm{Al}^{3+}{ }_{\mathrm{x}}\right) \mathrm{O}_{10}(\mathrm{OH})_{2}
\end{aligned}
$$

Smectites are widely demanded in most of industrial productions owing to their unique physical, chemical, mechanical, rheological and other properties, as well as their rich and spread natural deposits making them environmentally compatible and safe [4-8]. For operation with gases or volatile compounds $[9,10]$ and, currently, by cement and concrete productions [11] to be used as a source of cementitious materials, raw clays need to be activated. Most often thermal activation is applied, as a result of which molecules of $\mathrm{CO}_{2}, \mathrm{H}_{2} \mathrm{O}$ and other substances leave the surface providing an increase in porosity and specific surface of a sorbent [9-12]. However, the exposure of high temperature can be destructive for aluminosilicates irreversibly changing their layered structure $[1,4,12]$. Processes of dehydroxylation at $\mathrm{t}>300^{\circ} \mathrm{C}$ and amorphization at $\mathrm{t}>500^{\circ} \mathrm{C}$ of layered aluminosilicates are the reasons for a decline of their internal surface, loss of ability to swell, ionexchange and adsorb $[10,12,13]$. In addition, thermal exposure changes physicalchemical properties and, most often, increases free energy of the surface due to formation, redistribution or enhancing the accessibility of surface active site of acidbase or redox character $[14,15]$.

At ambient conditions, acid-base equilibrium of surface active site of natural clays is shifted towards their higher acidity [1416]. The contribution of basic sites of the surface (structural hydroxyls, adsorbed water, edge $\mathrm{OH}$-groups) becomes evident by the change of external conditions $(\mathrm{pH}$, temperature), chemical [17-20] or physical [2123] modification of aluminosilicates. In a number of processes basicity of catalyst or sorbent surface plays a decisive role [24, 25] that makes studies on basic properties of the surface under activation or modification of materials of current interest.

The aim of present studies included investigation of the effect of thermal activation on the character of distribution and a number of basic sites on the surface of natural layered aluminosilicates by means of the new method of inverse thermoprogrammed desorption of $\mathrm{CO}_{2}$.

Table 1. Phase and chemical composition of natural and modified aluminosilicate samples [19]

\begin{tabular}{|c|c|c|c|c|c|c|c|c|c|c|}
\hline \multirow{2}{*}{ Sample } & Phase composition & \multicolumn{7}{|c|}{ Chemical composition, \% } \\
\cline { 3 - 10 } $\mathrm{Mt}-0$ & $\begin{array}{c}\text { Montmorillonite } \\
67 \%, \text { illite 5\%, } \\
\text { quartz 5\%, feld- } \\
\text { spars 21\% }\end{array}$ & 59.48 & 23.34 & 2.89 & 2.09 & 2.38 & 1.14 & 1.62 & 0.24 & 6.61 \\
\hline Nt-0 & $\begin{array}{c}\text { Nontronite 70\%, } \\
\text { illite 10\%, kaolinite } \\
5 \%, \text { quartz 10\%, } \\
\text { feldspars 8\% }\end{array}$ & 66.06 & 13.84 & 6.41 & 0.2 & 1.78 & 0.99 & 1.4 & - & 6.34 \\
\hline
\end{tabular}




\section{Materials and methods}

Samples of natural aluminosilicates rich with montmorillonite (Mt-0) from Industrial Minerals $\mathrm{GmbH}$, Germany, and nontronite, Nt-0 from Voronezh deposit "Podgornoe" were chosen as objects of investigation. Phase and chemical compositions of investigated natural aluminosilicates samples were determined by XRD and XRF techniques [19] and represented in Table 1.

Specific surface area of the samples was calculated from the $\mathrm{N}_{2}$ adsorptiondesorption isotherms obtained at $-196^{\circ} \mathrm{C}$ using a TRISTAR 300 gas adsorption. Outgassing conditions included $2 \mathrm{~h}$ at $90^{\circ} \mathrm{C}$ followed by $8 \mathrm{~h}$ at $250^{\circ} \mathrm{C}$. BET-method was applied for calculation of specific surface area (SSA); BJH method for mesopores volume, and t-plot analysis were used for assessment of micropores volume.

Inverse thermal programmed desorption of $\mathrm{CO}_{2}$ (iTPD- $\mathrm{CO}_{2}$ ) was used to probe surface basicity and determine the number of basic sites. The new iTPD-technique [26] TPD- is based on the FID-detection of $\mathrm{CH}_{4}$ formed at an intermediate step of methanization of $\mathrm{CO}_{2}$ desorbed from the surface of investigated sample by a GC. A specially designed sample loop (SL) of a fixed volume $(250 \mu \mathrm{L})$ allows calibration of the FIDsignal of GC received from the measurement and thus quantitatively determine volume of desorbed $\mathrm{CO}_{2}$. For the iTPD- $\mathrm{CO}_{2}$ measurement $100 \mathrm{mg}$ of a sample was placed in to quartz U-tube reactor and acti-

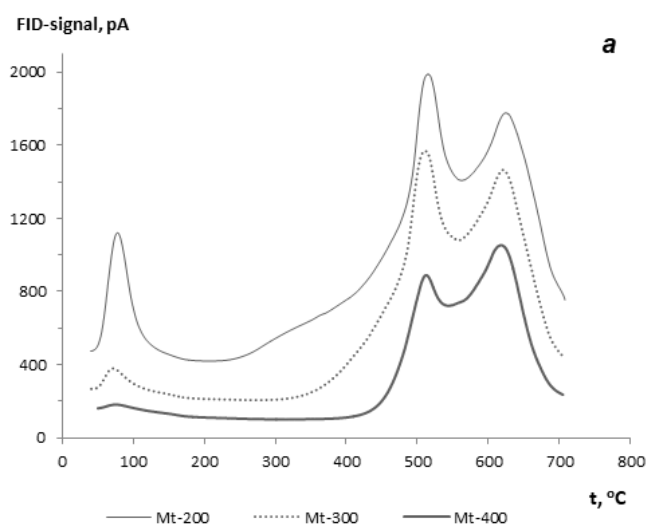

Fig. 1. iTPD-CO $\mathrm{CO}_{2}$-profiles of montmorillonite (1a) and nontronite (1b) activated at 200,300 and $400^{\circ} \mathrm{C}$ vated at different temperatures (200, 300, $400^{\circ} \mathrm{C}$ ) in the $\mathrm{N}_{2}$-flow for 8 hours. After that samples were loaded with $\mathrm{CO}_{2}$ in the $3 \mathrm{ml} / \mathrm{min}$ flow of $\mathrm{CO}_{2}$ for $30 \mathrm{~min}$ at ambient temperature. Next, the reactor was flushed by $5 \mathrm{ml} / \mathrm{min} \mathrm{N}_{2}$-flow to desorb weakly sorbed $\mathrm{CO}_{2}$. At further step, the profile of iTPD- $\mathrm{CO}_{2}$ was recorded within the 20$800^{\circ} \mathrm{C}$ temperature range at a heating rate of $20^{\circ} \mathrm{C} / \mathrm{min}$ with a total duration of TPD of $90 \mathrm{~min}$. The iTPD- $\mathrm{CO}_{2}$ profiles were treated using ChemStation software.

\section{Results and discussion}

iTPD- $\mathrm{CO}_{2}$ profiles of montmorillonite and nontronite samples treated at different temperatures are given in Fig.1.

As follows from the Fig.1, there were two temperature regions of the $\mathrm{CO}_{2}$ desorption in the profiles of $\mathrm{Mt}$ and $\mathrm{Nt}$ samples. Low temperature peaks evolved around 80$90^{\circ} \mathrm{C}$ for Mt and between $110-127^{\circ} \mathrm{C}$ for $\mathrm{Nt}$ were most likely related to the weak basic sites [27], whereas high temperature peaks around 510 and $620{ }^{\circ} \mathrm{C}$ for $\mathrm{Mt}$ and above $320^{\circ} \mathrm{C}$ for $\mathrm{Nt}$ testified to stronger ones. To reason the obtained iTPD-profiles one should consider thermal behavior of layered aluminosilicates [28] as dehydration state and products will determine surface properties. It is well confirmed by thermal analysis that smectites and dioctahedral 2:1 layered silicates loose water in three temperature ranges: i) dehydration at $<220^{\circ} \mathrm{C}$ involving loss of $\mathrm{H}_{2} \mathrm{O}$ from the interlayer space of expandable clays; ii) $\mathrm{OH}$ groups

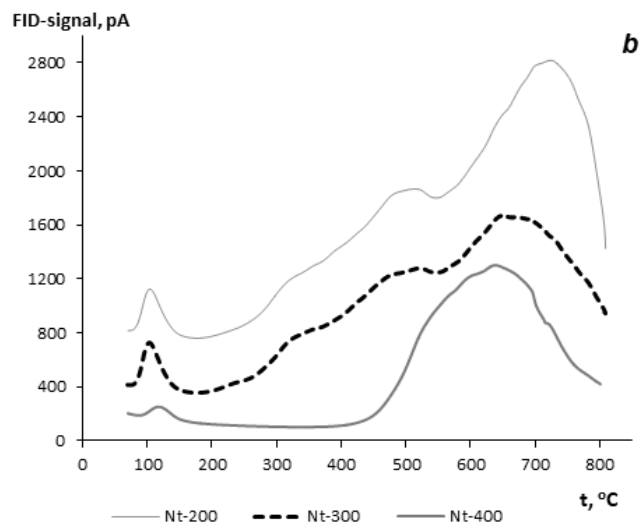


bound to the surface between $220-350^{\circ} \mathrm{C}$, and iii) dehydroxylation between 350$1000^{\circ} \mathrm{C}$ resulting from the reaction between the octahedral hydroxyls. Due to this, gradual decrease in the intensities of the low temperature peaks at higher activation temperatures testified to a decrease in the weak basic sites related to hydroxyl groups of adsorbed water molecules. As shown for Na-Mt [27] 23\% of basic sites were weak and caused desorption between 20 and $110^{\circ} \mathrm{C}$, whereas at $140-200^{\circ} \mathrm{C} \mathrm{CO}_{2}$ desorption was caused by medium strength basic sites accounting for $42 \%$.

Elevation of activation temperature from 200 to $400^{\circ} \mathrm{C}$ caused further dehydration of the samples and a decrease in the number of weak surface sites. Moreover, at temperatures above $200^{\circ} \mathrm{C}$ there is a process of dehydroxylation of structural hydroxyls Al$\mathrm{OH}, \mathrm{Fe}-\mathrm{OH}, \mathrm{Mg}-\mathrm{OH}$, which becomes irreversible above $300^{\circ} \mathrm{C}$ due to damage of the 2:1 layered structure of aluminosilicates. As shown in [29], mainly octahedral hydroxyls dehydroxylate according to a scheme 2 $\left(\mathrm{OH}^{-}\right)=\mathrm{H}_{2} \mathrm{O}+\mathrm{O}^{2-}$, providing formation of residual oxygen atoms in the structure and their contribution to population of stronger basic sites along with octahedral hydroxyls. As dehydroxylation of dioctahedral smectites typically has a duplet on DTA curve due to earlier dehydroxylation of transvacant (tv) $\mathrm{Al}-\mathrm{OH}$ groups $\left(\sim 550^{\circ} \mathrm{C}\right)$, while that for cis-vacant (cv) Al-OH appears at higher temperature $\left(\sim 650^{\circ} \mathrm{C}\right)[30]$, it is similarly assumed that strong basic sites of Mt sample are represented by correspond- ingly trans- and cis-vacant Al-OH groups. The distance between the adjacent $\mathrm{OH}-\mathrm{OH}-$ groups is shorter in tv- (2.45 A [30]) then in cv- (2.85 A [30]) dioctahedral 2:1 layer minerals that facilitates dehydroxylation of tv-Al-OH groups and, hence, determines variations in the strength of basic sites formed. Redistribution of A1-O and Al-OH bond strengths due to migration of Al cations to empty five-coordinated sites testifies to heterogeneity of aluminous cv-layers dehydroxylation [30, 31].

In case of Nt sample, the distribution of strong basic sites is more heterogeneous as follows from the shoulder and overlapped peaks at $350-650^{\circ} \mathrm{C}$. Variation of chemical composition of $\mathrm{Nt}$ from $\mathrm{Mt}$, mainly, in the octahedral sheet strongly affects their surface sites distribution, thermal behavior and $\mathrm{CO}_{2}$ sorption ability. It was confirmed for Fe-rich smectites (nontronites) and micas (glauconites, celadonites) consisting of tv 2:1 layers that they rapidly loose hydroxyls at significantly lower temperature as compared to Al-rich samples [30, 32]. Indeed, iTPD-CO $\mathrm{C}_{2}$ profiles of Nt samples (Fig. 1b), rich in $\mathrm{Fe}$, differs from those of Mt samples by the broad and insufficiently resolved high temperature region. Apart from week basic sites, formed around $100^{\circ} \mathrm{C}$, formation of stronger basic sites started above $300^{\circ} \mathrm{C}$ and resulted in heterogeneous distribution of various strength basic sites. One may distinguish three different basic sites attributed to i) shoulders around $315-320^{\circ} \mathrm{C}$ (Nt-200, Nt-300), ii) maxima at $480^{\circ} \mathrm{C}$ (Nt200, Nt-300) and iii) maxima at $700^{\circ} \mathrm{C}$ (Nt-

Table 2. Volume of desorbed $\mathrm{CO}_{2}\left(\mathrm{~V}_{\mathrm{CO}}, \mu \mathrm{L} / \mathrm{g}\right)$ and surface basicity of montmorillonite and nontronite activated at various temperatures

\begin{tabular}{|c|c|c|c|c|c|c|c|}
\hline \multirow[b]{2}{*}{ Sample } & \multirow{2}{*}{$\begin{array}{l}\mathrm{T}_{\text {act }}, \\
{ }^{\circ} \mathrm{C}\end{array}$} & \multirow{2}{*}{$\begin{array}{c}\mathrm{S} \\
\mathrm{m}^{2} / \mathrm{g}\end{array}$} & \multicolumn{2}{|c|}{$\begin{array}{c}\text { Volume of desorbed } \mathrm{CO}_{2}, \\
\mu \mathrm{L} / \mathrm{g}\end{array}$} & \multirow{2}{*}{$\begin{array}{c}\text { Total } \mathrm{V}_{\mathrm{CO} 2} \\
\text { desorbed, } \\
\mu \mathrm{L} / \mathrm{g}\end{array}$} & \multirow{2}{*}{$\begin{array}{c}\text { Total } \\
\text { number of } \\
\text { basic sites, } \\
\mathrm{B}_{\Sigma}, \\
\mu \mathrm{mol} / \mathrm{g}\end{array}$} & \multirow{2}{*}{$\begin{array}{c}\text { Specific } \\
\text { basicity of } \\
\text { surface, } \\
\mathrm{B}_{\Sigma} / \mathrm{S}, \\
\mu \mathrm{mol} / \mathrm{m}^{2}\end{array}$} \\
\hline & & & $\begin{array}{c}\text { Weak } \\
\text { basic sites }\end{array}$ & $\begin{array}{c}\text { Strong } \\
\text { basic sites }\end{array}$ & & & \\
\hline \multirow{3}{*}{ Mt-0 } & 200 & \multirow{3}{*}{43} & 19.4 & 450.8 & 470.2 & 209.9 & 4.9 \\
\hline & 300 & & 3.8 & 363.3 & 367.1 & 163.9 & 3.8 \\
\hline & 400 & & 0.9 & 207.9 & 208.8 & 93.2 & 2.2 \\
\hline \multirow{3}{*}{$\mathrm{Nt}-0$} & 200 & \multirow{3}{*}{105} & 14.6 & 790.0 & 804.6 & 359.2 & 3.4 \\
\hline & 300 & & 14.0 & 561.5 & 575.5 & 256.9 & 2.5 \\
\hline & 400 & & 5.1 & 341.8 & 346.9 & 154.9 & 1.5 \\
\hline
\end{tabular}


200) and $640^{\circ} \mathrm{C}$ (Nt-300), and testifying to their strength enhancement.

It follows from table 2 that total basicity of Nt samples 1.6-1.7 times that of Mt, obviously, due to its phase and chemical composition from one side and developed surface area and porosity as well. At the same time, Mt samples had slightly higher number of weak sites as Nt, which are easily lost by rising temperature from 200 to $300^{\circ} \mathrm{C}$ as compared to Nt. As activation temperature rose from 200 to $400^{\circ} \mathrm{C}$, the number of weak sites for Mt decreased by 21 times whereas for $\mathrm{Nt}$ by 2.8 times. Moreover, the ratio of stronger sites number to weak sites significantly increased (from 23 to 200) for Mt activated at higher temperatures, whereas for $\mathrm{Nt}$ this ratio varied between 54-67 times for the applied activation temperatures. In general, total basicity of both $\mathrm{Mt}$ and $\mathrm{Nt}$ decreased by 2.2-2.3 times at thermal activation as a result of their dehydration and dehydroxylation.

To compare the basicity of unit area of the minerals surface, one may normalize the obtained basicity value $\mathrm{B}_{\Sigma}, \mu \mathrm{mol} / \mathrm{g}$, per unit surface area and produce values of $\mathrm{B} \Sigma / \mathrm{S}$, $\mu \mathrm{mol} / \mathrm{m}^{2}$, given in Table 2 . The values of $\mathrm{B} \Sigma / \mathrm{S}$ testified that basicity of the unit area of Mt surface was 1.5 times higher than that of Nt surface obviously due to a higher occupancy and density of active sites for Mt.

\section{Conclusion}

Applying the iTPD-CO $\mathrm{CO}_{2}$ technique it was shown that surface of natural and thermally treated layered aluminosilicates of smectite group possesses one type of weak basic sites and a spectrum of strong basic sites. The number of weak basic sites for both Mt and $\mathrm{Nt}$ strongly depended on activation temperature applied and fast decreased due to the loss of loosely bound water molecules at elevating temperature. The distribution of strong basic sites was bimodal for Mt surface and, presumably, was primarily caused by presence of cis-vacant and transvacant Al-OH groups in octahedral sheet of the mineral. The Nt sample observed heterogeneous distribution of stronger basic sites represented by $\mathrm{Fe}^{3+}-\mathrm{OH}-\mathrm{Al}^{3+}$ and $\mathrm{Fe}^{3+}-\mathrm{OH}-$ $\mathrm{Fe}^{3+}$ in the octahedral sheets proving thermal sensitivity of Fe-rich smectites. The total basicity and total volume of $\mathrm{CO}_{2}$ adsorbed by $\mathrm{Nt}$ samples exceeds that of $\mathrm{Mt}$ in 1.6-1.7 times. Nevertheless, the determined value of specific basicity of unit area of $\mathrm{Mt}$ surface was 1.5 times higher than that of $\mathrm{Nt}$ obviously due to variations in chemical and phase composition of samples that resulted in a higher density of active sites of Mt containing sample. The rise of activation temperature from 200 to $400^{\circ} \mathrm{C}$ resulted in a 2.2-2.3 times drop of total basicity of both $\mathrm{Mt}$ and $\mathrm{Nt}$ samples as a consequence of their dehydration and dehydroxylation.

The authors acknowledge the EU Research Agency and the $7^{\text {th }}$ Framework program of EU for supporting the studies within the FP7-PEOPLE-IRSES-295260 "ECONANOSORB" project.

\section{References}

1. Bergaya F., Lagaly G. Handbook of clay science, 2013, Elsevier, Netherlands. 874 p.

2. M.J. Wilson. Rockforming minerals, Geological society of London, 1978. $724 \mathrm{p}$.

3. Ogorodova L.P., Kiseleva I.A., Melchakova L.V., Vigasina M.F. et al., Geochemistry International, 2014, Vol. 52, No 5, pp. 421427.

4. Humphrey J.P., Boyd D.E. Clay: Types, Properties, and Uses, Nova Science Publishers, 2011, 493 p.
5. Koshevar V.D. Organomineral'nye dispersii. Regulirovanie ih svojstv i primenenie. Minsk, Belorus nauka, 2008. 312 p.

6. Christidis G.E. Assessment of Industrial Clays in Developments in Clay Science, 2013, Vol. 5, pp. 425-449

7. Novikova L., Belchinskaya L., Clays, Clay Minerals and Ceramics Materials Based on Clay Minerals, InTechOpen, 2016, pp. 89-128. doi: $10.5772 / 61678$. 
8. Romanov V. Greenhouse Gases and Clay Minerals: Enlightening Down-to-Earth Road Map to Basic Science of ClayGreenhouse Gas Interfaces, Springer, 2017. $187 \mathrm{p}$.

9. Belchinskaya L.I., Khodosova N.A., Novikova L.A., Sorbtsionnye $i$ khromatograficheskiye protsessy, 2017, Vol. 17, No 5. pp. 781-791. https://doi.org/10.17308/ sorpchrom.2017.17/439

10. Deng L., Yuan P., Liu D., AnnabiBergaya F., Zhou J. et al., Applied Clay Science, 2017, Vol. 143, pp. 184-191.

11.Tironi A., Trezza M.A., Irassar E.F., Scian A.N., Procedia Materials Science, 2012, Vol. 1, pp. 343-350.

12.Sarikaya Y., Önal M., Baran B., Alemdaroğlu T., Clays and Clay Minerals, 2000, Vol. 48, pp. 557-562.

13.Padilla-Ortega E., Medellín-Castillo N., Robledo-Cabrera A., Journal of Environmental Chemical Engineering, 2020, Vol. 8, 103850. https://doi.org/10.1016/j.jece.2020.103850

14. Novikova L.A., Roessner F., Belchinskaya L.I., Alsawalha M. et al., Applied Clay Science, 2014, Vol. 101, pp. 229-236. http://dx.doi.org/10.1016/j.clay.2014.08.005.

15.Belchinskaya L.I., Khodosova N.A., Novikova L.A., Strelnikova O.Yu. et al., Physical chemistry of surface and protection of materials, 2016, Vol. 52, No 4, pp. 599-606. doi:10.1134/S2070205116040055

16. Liu X., Cheng J., Sprik M., Lu X. et al., Geochimica et Cosmochimica Acta, 2014, Vol. 140, pp. 410-417. https://doi.org/10.1016 j.gca.2014.05.044

17. Timofeeva M.N., Panchenko V.N., Gil A., Zakusin S.V. et al., Catalysis Communications, 2015, Vol 69, pp. 234-238. https://doi.org/10.1016/j.catcom.2015.07.005

18. Belchinskaya L.I., Khodosova N.A., Strelnikova O.Yu., Petukhova G.A. et al., Protection of metals and physical chemistry of surfaces, 2015, Vol.51, No 5, pp. 779-876.

19. Krupskaya V., Novikova L., Tyupina E., Belousov P. et al., Applied Clay Science, 2019,
Vol. 172, pp. 1-10. doi.org/10.1016/ j.clay.2019.02.001

20.Kotova D.L., Sokrukina A.I., Krysanova T.A., Sorbtsionnye $i$ khromatograficheskiye protsessy, 2019, Vol. 2, pp. 174-178. https:// doi.org/10.17308/sorpchrom.2019.19/735

21.Kotova D.L., Artamonova M.N., Krysanova T.A., Vasilenko M.S. et al., Protection of Metals and Physical Chemistry of Surfaces, 2018, Vol. 54, No 3, pp. 347-351.

22.Kotova D. L., Krysanova T. A., Novikova L.A., Belchinskaya L.I. et al., Sorbtsionnye $i$ khromatograficheskiye protsessy, 2020, Vol. 20, No 2, pp. 166-174. https://doi.org /10.17308/sorpchrom.2020.20/2771

23.Rudmin M., Banerjee S., Yakich T., Tabakaev R. et al., Applied Clay Science, 2020, Vol. 196, pp. 105775. https://doi.org/10.1016/ j.clay.2020.105775

24.Li Y., Sabbaghi A., Huang J., Chun Li K. et al., Molecular Catalysis, 2020, Vol. 485, 110789. https://doi.org/10.1016/j.mcat.2020. 110789

25.Hattori H., Chem. Rev., 1995, Vol. 95, pp. 537-550

26.Roessner F., Schoenen S. Patent. WO 2011/134934 A1, 03.11.2011.

27.Azzouz A., Nousir S., Platon N., Ghomai $\mathrm{K}$. et al., International journal of greenhouse gas control, 2013, Vol. 17, pp.140-147.

28.Heller-Kallai L. Chapter 10.2. Thermally Modified Clay Minerals in Developments in Clay Science, 2013, Vol. 5, pp. 411-433

29.Emmerich K., Thule Madsen F., Kahr G., Clay and Clay Minerals, 1999, Vol. 47, No 5, pp. 591-604.

30.Drits V., Besson G., Muller F., Journal de Physique IV Colloque, 1996, Vol. 06 (C4), pp. C4-91-C4-102.

31.Dritz V.A., Besson G., Muller F., Clays \& Clay Miner., 1995, Vol. 43, No 6, pp. 718-731.

32.Andrejkovichova S., Madejova J., Czimerova A., Galko I. et al., Geologica Carpathica, 2006, Vol. 57, No 5, pp. 371-378. 


\title{
Влияние температуры активации на основность поверхности природных алюмосиликатов
}

\author{
(C) 2021 Новикова Л.А. ${ }^{1}$, Ходосова Н.А. ${ }^{1}$, Бельчинская Л.И. ${ }^{1}$, Ресснер Ф. ${ }^{2}$ \\ ${ }^{1}$ Воронежский государственный лесотехнический университет им. Г.Ф. Морозова, \\ Воронеж, Российская Федерация \\ ${ }^{2}$ Ольденбургский университет им. Карла фон Оссеикого, Ольденбург, Германия
}

\begin{abstract}
Монтмориллонит и нонтронит представляют слоистые алюмосиликаты группы смектита, которые широко востребованы во многих промышленных производствах благодаря своим физикохимическим и многим другим свойствам. Термическая активация глинистого сырья изменяет пористость, удельную поверхность и физико-химические свойства поверхности, включая образование и перераспределение поверхностных активных центров кислотно-основного или окислительновосстановительного характера. Целью данного исследования явилось изучение эффекта термической активации на характер распределения и количество основных центров поверхности природных слоистых алюмосиликатов с помощью усовершенствованного метода обращенной термопрограммированной десорбции $\mathrm{CO}_{2}$.
\end{abstract}

Образцы природных алюмосиликатов, богатые монтмориллонитом (монтмориллонит 67\%, иллит $5 \%$, кварц $5 \%$, полевой шпат $21 \%$ ) и нонтронитом (нонтронит $70 \%$, иллит $10 \%$, каолинит $5 \%$, кварц $10 \%$, полевой шпат $8 \%$ ) были охарактеризованы методами XRD, XRF, BET адсорбции $\mathrm{N}_{2}$. Для исследования основности поверхности и определения количества основных центров был использован новый метод iTPD-CO ${ }_{2}$. Перед измерением іTPD- $\mathrm{CO}_{2} 100$ мг образца активировались при 200, 300, $40 \mathrm{~cm}^{3} /$ мин, 30 мин). Далее, реактор промывался потокам азота при скорости $5 \mathrm{~cm}^{3} /$ мин для десорбирования слабо связанного $\mathrm{CO}_{2}$. Профили iTPD- $\mathrm{CO}_{2}$ снимали в интервале $20-800^{\circ} \mathrm{C}$ при скорости нагрева $20^{\circ} \mathrm{C} /$ мин и обрабатывали в программе ChemStation.

Экспериментальные профили десорбции $\mathrm{CO}_{2}$ для образцов Mt и $\mathrm{Nt}$ характеризовались присутствием двух температурных участков. Низкотемпературные пики, обнаруженные около $80-90^{\circ} \mathrm{C}$ для $\mathrm{Mt}$ и около $110-127^{\circ} \mathrm{C}$ для $\mathrm{Nt}$, скорее всего связаны со слабыми основными центрами, тогда как высокотемпературные пики около 510 и $620^{\circ} \mathrm{C}$ для $\mathrm{Mt}$ и выше $320^{\circ} \mathrm{C}$ для $\mathrm{Nt}$ указывают на более сильные основные центры. Объяснение полученных профилей iTPD проведено с учетом термического поведения слоистых алюмосиликатов.

Общая основность образцов Nt и Mt составила 359.2 и 209.9 мкмоль/г соответственно. Основность $\mathrm{Nt}$, превышающая в 1.6 раза таковую для Mt, очевидно связана с его фазовым и химическим составом и более развитой удельной поверхностью, и пористостью. При повышении температуры активации число слабых основных центров, связанных с гидроксильными группами воды, постепенно снижалось, составив уменьшение в 21 раз для $\mathrm{Mt}$ и 2.8 раза для $\mathrm{Nt}$.

Дегидроксилирование структурных $\mathrm{Al}-\mathrm{OH}, \mathrm{Fe}-\mathrm{OH}, \mathrm{Mg}-\mathrm{OH}$ выше $200^{\circ} \mathrm{C}$, переходящее в необратимое при температурах выше $300^{\circ} \mathrm{C}$, привело к образованию остаточных атомов кислорода и их вкладу к общее количество более сильных основных центров. В соответствии с термическим поведением диоктаэдрических смектитов, предполагается, что сильными основными центрами образца $\mathrm{Mt}$ являются trans- и cis-вакантные Al-OH группы, дегидроксилирующие соответственно при $\sim 550^{\circ} \mathrm{C}$ и $650^{\circ} \mathrm{C}$. Образей $\mathrm{Nt}, \mathrm{c}$ повышенным содержанием железа, быстро терял гидроксилы при более низких темпартурах, что при отразилось в более гетерогенном распределении основных центров различной силы. При повышении температуры активации отношение числа сильных основных центров к слабым повысилось с 23 до 200 для образца Mt, тогда как для Nt это отношение составило 54-67 раз. В целом, общая основность Mt и Nt снизилась в 2.2-2.3 раза в следствие их дегидратации и дегидроксилирования при термической активации. Нормализованные значения основности на единицу площади поверхности $\left(\mathrm{B}_{\Sigma} / \mathrm{S}\right.$, мкмоль/ $\left.\mathrm{M}^{2}\right)$ оказались в 1.5 раза выше для образца $\mathrm{Mt}$, что очевидно указывает на более высокую занятость поверхности и плотность расположения активных центров для Мt в сравнении с Nt.

Ключевые слова: монтмориллонит, нонтронит, термическая активация, обращенная термопрограммированная десорбция $\mathrm{CO}_{2}$, основность поверхности.

Новикова Людмила Анатольевна - к.х.н., доцент кафедры химии Воронежского государственного лесотехнического университета им. Г.Ф. Морозова, Воронеж
Novikova Lyudmila A. - Ph.D (Chemistry), associate professor at the department of chemistry, Voronezh State University of Forestry and Technologies named after G.F. Morozov, Voronezh; chem@,vgltu.ru 
Ходосова Наталия Анатольевна - к.х.н., до- Khodosova Natalia A. - Ph.D (Chemistry), asцент кафедры химии Воронежского государ- sociate professor at the department of chemistry, ственного лесотехнического университета им. Voronezh State University of Forestry and TechГ.Ф. Морозова, Воронеж nologies named after G.F. Morozov, Voronezh

Бельчинская Лариса Ивановна - д.т.н., про- Belchinskaya Larissa I. - doctor of technical sciфессор кафедры химии Воронежского государ- ences, professor at the department of chemistry, Voственного лесотехнического университета им. ronezh State University of Forestry and TechnoloГ.Ф. Морозова, Воронеж gies named after G.F. Morozov, Voronezh

Рёсснер Франк - д.х.н., профессор кафедры промышленной химии Ольденбургского университета им. К. Осецкого, Ольденбург, Германия

Roessner Frank - Dr. Chem. Sci., professor at the department of industrial chemistry, Carl von Ossietzky University of Oldenburg, Oldenburg, Germany 